\title{
The Roman Division of Wrongs: A New Hypothesis
}

\author{
Eric Descheemaeker*
}

\begin{abstract}
This article examines the rationale of the Justinianic division of wrongs into delicts and "quasi-delicts." Taking as its starting point the assumption that the distinction corresponded to that between fault- (culpa-) based and situational liability, it hypothesizes that the quasi-delictal appendix arose after the time of Gaius' Institutes from a contraction of the Roman concept of a civil wrong (delictum): its scope would have narrowed from an unlawful liability-creating act to a blameworthy such act, thereby rejecting, outside of the delictal class proper, instances of liability regardless of fault.
\end{abstract}

\section{Introduction}

One important feature of post-classical Roman law, as reflected in Justinian's Institutes, is that it divided what we would call today its law of civil wrongs into two groups: some obligations from unlawful, non-criminal events were said to arise ex delicto ("from a delict"), while others were deemed to arise quasi ex delicto ("as if from a delict"). The dividing line between delicts and "quasi-

* Fellow and Tutor in Law, St. Catherine's College, University of Oxford; and Lecturer in Law, University of Bristol. This article is a revised version of parts of two chapters from my doctoral thesis (E. Descheemaeker, The Division of Wrongs: A Historical Comparative Study (Oxford 2009)). I owe particular debts of gratitude to the late Peter Birks and Professor David Ibbetson, who supervised the work, and to Professors Simon Whittaker and Reinhard Zimmermann, who examined it. I am also grateful to Professor Ernest Metzger for helpful comments on this piece. Any remaining mistakes are naturally mine alone.

Throughout this article, references to "Birks and McLeod" are to P. Birks and G. McLeod, eds., Justinian's Institutes (London and Ithaca, NY 1987); references to "Gordon and Robinson" are to W. M. Gordon and O. F. Robinson, eds., The Institutes of Gaius (London 1988); and references to the "Watson Digest" are to A. Watson, ed., The Digest of Justinian [revised English-language edition] (Philadelphia 1998). 
delicts" ${ }^{1}$ has been the subject of a wealth of scholarly literature. I have argued elsewhere ${ }^{2}$ that the dichotomy corresponded to the divide between fault-based and situational liability, ${ }^{3}$ and the discussion will not be reopened in the present article. This hypothesis will be taken as a starting point.

What has not, on the other hand, been the object of much attention on the part of Romanists is the rationale of the division: why was such a distinction made between wrongs proper and "quasi-wrongs"? Because some modern jurisdictions like Scotland and France have retained a similar division (even if it is devoid of practical significance), we might not regard the twofoldness of the Roman law of wrongs as immediately problematic; yet historical longevity provides no explanation for its having come into existence in the first place. That the Roman division needs to be accounted for is all the truer because it did not always exist. In Gaius' Institutes (written ca. AD 135), ${ }^{4}$ only one class of wrongs is being mentioned; and the existence of a second category, or an appendix, is not even suggested. Thus, from a historical perspective, the above question can be rephrased differently: why did Roman law decide, at some stage of its historical development, to split its law of wrongs into two?

1 The term is in inverted commas because it was not used until after Justinian's codification. The first occurrence of the term "quasi delicton" (and, in parallel, of "quasi contracton," both in Hellenized Latin) is to be found in Theophilus' Greek paraphrase of the Institutes (see E. C. Ferrini, ed., Institutionum Graeca Paraphrasis Theophilo Antecessori, 2 (Berlin 1967), $\S \S 3.27 .3,5 ; 4.5$ pr.). The Basilica would then speak in the ninth

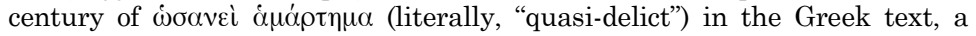
term later rendered in the Latin version as "quasi delictum" (K. W. E. Heimbach, Basilicorum libri LX, 5 (Leipzig 1850), 327). While it is convenient to call "quasi-delicts" the events from which obligations quasi ex delicto arise, it conceals the fact that the Romans never gave a name to this class of causative events. It also confuses quasi as a conjunction (meaning "as if") and quasi as an adverb ("almost").

2 E. Descheemaeker, The Division of Wrongs: A Historical Comparative Study (Oxford 2009), 67, 69-99.

3 The term "situational liability" is used to describe liability arising from the occurrence of a particular factual situation. While it is generally synonymous with the more widely used "no-fault" and "strict liability," it is a better phrase because it emphasizes the fact that it is not simply liability without fault or even liability regardless of fault, but liability imposed without the question of fault coming into the picture in the first place: subject to possible justifications (themselves unrelated to fault), liability arises immediately from the occurrence of a particular factual situation.

4 The date is based on Professor Honoré's reconstructed chronology of Gaius' works: see A. M. Honoré, Gaius (Oxford 1962), 69. 
The answer necessarily belongs to what can be described as the "classificatory stream" of Roman law. The actional system around which Roman law grew did not think in terms of actions ex delicto or quasi ex delicto, and neither did the bulk of legal literature which followed the edictal order. Such a classification of actions (and of the corresponding obligations) belongs essentially to Gaius and Justinian. If the rationale of the Roman division of wrongs (or, which comes to the same, of the appearance of the quasi-delictal appendix) can be found at all, it will have to be in the transition from Gaius' single class of wrongs to Justinian's twofold structure. This is what this article will focus upon.

In the first two sections, I shall lay out the relevant texts and analyse the shortcomings of their traditional interpretation in terms of the addition of new classes of causative events. In the third section an alternative explanation will be defended, which finds the origin of the appendix in the contraction of the original class, a contraction that was brought about by the narrowing down of the concept of a wrong (delictum) over the classical period.

\section{The Structural Framework}

The starting point of this paper was the distinction drawn in Justinian's Institutes between wrongs and "quasi-wrongs," or more accurately between obligations ex delicto and quasi ex delicto. ${ }^{5}$ The scope of the enquiry must immediately be widened because this division features in the context of a larger, fourfold classification of the events from which obligations arise:

J.3.13.2. Aut enim ex contractu sunt aut quasi ex contractu aut ex maleficio aut quasi ex maleficio.

5 A difficult issue of translation arises here: should "delictum" be straightforwardly anglicized into "delict," or can it legitimately be translated by the English word "wrong"? Logically, the answer depends on what is meant by "wrong"; in particular, if the definition of wrong is cast broadly enough, it will encompass Roman "quasi-delicts" as well as delicts proper, leaving no room for obligations "as if from a wrong." The problem is that the definition of a wrong is not stable or univocal, neither from a jurisprudential nor from a historical perspective. As this paper will attempt to show, the scope of the concept evolved even in the course of the development of Roman law. This makes it all but impossible to find an analytically satisfactory translation. The present article will simply use "delict" and "wrong" as alternative, both imperfect, renderings for "delictum." 
[Obligations] arise from a contract, as though from a contract, from a wrong, or as though from a wrong. (Trans. Birks and McLeod.)

For the present purposes, two assumptions (neither of which is controversial) will be made in respect of this classification. The first one is that the distinction between, on the one hand, obligations ex contractu and quasi ex contractu and, on the other hand, obligations ex delicto and quasi ex delicto is that the former arise from lawful causative events while the latter arise from unlawful such events. The second assumption is that, within lawful events, the line between contract and "quasi-contract" corresponds to the presence or absence of conventio, i.e. an agreement of the minds of the parties.

If these, and the basis for the division between delicts and "quasi-delicts" which was taken as a working hypothesis, are correct, the substance of Justinian's fourfold classification can then be summarized as follows:

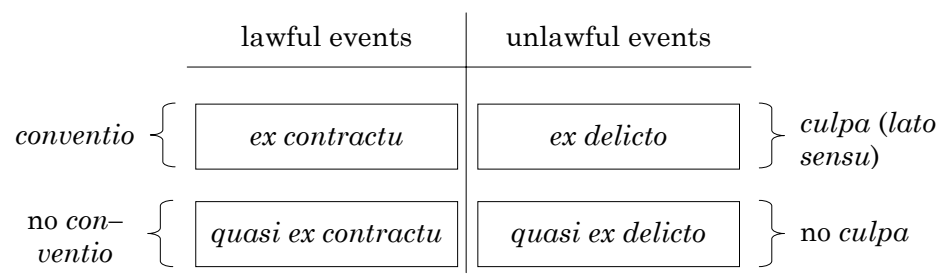

Fig. 1 - The Quadripartition of Obligations in Justinian's Institutes

Justinian's position was the end point of the development of Roman law (in its first life). In terms of the classification of obligations, within which the division of wrongs arose, the starting point was Gaius' Institutes, of which Justinian's were essentially a new edition almost four centuries later. Although the structure of both books, known as the institutional scheme, is (apart from some low-level adjustments) the same, a significant variation can be found when it comes to the classification of causative events. For Gaius, the number of categories of events from which obligations arose was only two:

G.3.88. Nunc transeamus ad obligationes, quarum summa divisio in duas species diducitur: omnis enim obligatio vel ex contractu nascitur vel ex delicto. 
We turn to obligations. They divide first into two: all obligations arise from a contract or from a wrong. (Trans. Gordon and Robinson, revised.)

However, this passage is followed almost immediately by another which appears to show that Gaius might have doubted or even denied this proposition:

G.3.91. Is quoque, qui non debitum accepit ab eo, qui per errorem solvit, re obligatur; nam proinde ei condici potest SI PARET EUM DARE OPORTERE, ac si mutuum accepisset. . . . Sed haec species obligationis non videtur ex contractu consistere, quia is, qui solvendi animo dat, magis distrahere vult negotium quam contrahere.

A person also incurs an obligation by conduct if he receives something not due to him from a person who pays him by mistake. This recipient is just as much caught by the words of that action - "if it appears that he has a duty to give" - as if he had been given a loan. ... But here the obligation cannot be said to arise from contract. Someone who gives intending to discharge a debt means, not to tie up a deal, but to untie one, "distrahere" not "contrahere." (Trans. Gordon and Robinson.)

Thus Gaius acknowledged, at least on the face of it, two classes of causative events and Justinian four; Justinian had a division of wrongs while Gaius did not. In other words, the Roman division of wrongs arose in the passage from G.3.88 to J.3.13.2. It is this transition that needs to be examined if we want to understand the rationale of Justinian's dichotomy.

In the whole surviving literature, there is only one text besides these two which deals with the question of the classification of obligations. ${ }^{6}$ It is a fragment of Gaius' Res cottidianae, which

6 We can safely ignore the untidy enumeration of D.44.7.52 pr. (Modestinus 2 reg.): Obligamur aut re aut verbis aut simul utroque aut consensu aut lege aut iure honorario aut necessitate aut ex peccato. ("We are obliged either by conduct or by words or by both at the same time or by consent or by statute or by praetorian law or by necessity or by wrongdoing." Trans. Watson Digest, revised.) A number of other texts appear to assume the above contract/delict dichotomy, e.g. D.5.3.14 (Paul 20 ed.), D.5.1.57 (Ulpian $41 S a b$.$) , D.14.5.4.2 (Ulpian 29$ ed.). As far as the "quasicategories" are concerned, there is no mention of them anywhere between Gaius and Justinian. The expression quasi ex delicto venerit liberti appears in a fragment of the formula Fabiana attributed to Paul; but Girard must be right that its use is fortuitous (P. Girard, Textes de droit romain, 5th ed. (Paris 1923), 457). 
were possibly a posthumous edition of his Institutes and are only known through extracts in the Digest. The passage is particularly important because it provides the basis for these bits in Justinian's Institutes which were not lifted from Gaius' eponymous work. The text starts by resorting to a threefold classification of causative events: ${ }^{7}$

D.44.7.1 pr. (Gaius 2 rerum cottidianarum). Obligationes aut ex contractu nascuntur aut ex maleficio aut proprio quodam iure ex variis causarum figuris.

Obligations arise either from a contract or from a wrong or by operation of law: the latter can take various forms.

It then continues in a manner which appears to be intended to break the residual miscellany in two groups:

D.44.7.5 pr.-6 (Gaius 3 rerum cottidianarum). Si quis absentis negotia gesserit . . . si vero sine mandatu . . . placuit quidem sane eos invicem obligari... . Sed neque ex contractu neque ex maleficio actiones nascuntur... 1. Tutelae quoque iudicio qui tenentur, non proprie ex contractu obligati intelleguntur ... sed quia sane non ex maleficio tenentur, quasi ex contractu teneri videntur. .. . 2. Heres quoque, qui legatum debet, neque ex contractu neque ex maleficio obligatus esse intellegitur. ... 3. Is quoque, qui non debitum accipit per errorem solventis, obligatur quidem quasi ex mutui datione ... sed non potest intellegi is, qui ex ea causa tenetur, ex contractu obligatus esse. .. . 4. Si iudex litem suam fecerit, non proprie ex maleficio obligatus videtur, sed quia neque ex contractu obligatus est utique peccasse aliquid intellegitur, licet per imprudentiam, ideo videtur quasi ex maleficio teneri. 5. Is quoque, ex cuius cenaculo . . . deiectum effusumve aliquid est ita ... quasi ex maleficio teneri videtur. . . . Cui similis est is, qui ea parte, qua volgo iter fieri solet, id positum aut suspensum habet, quod potest, si ceciderit, alicui nocere. . . 6. Item exercitor navis aut cauponae aut stabuli de damno aut furto, quod in nave aut caupona aut stabulo factum sit, quasi ex maleficio teneri videtur ....

If someone has administered the affairs of an absent person . . . if the administration was without a mandate . . it was clearly accepted indeed that they are bound to each other. . . . However, the actions arise neither from contract, nor from a

7 The translation is adapted from Honoré (note 4), 99. 
wrong. . . . 1. Also persons who are liable in an action on tutelage are not considered, properly speaking, to be bound by contract . . . but because they are not liable in wrong, they are regarded to be liable as though from a contract. . . 2. Also an heir who owes a legacy is considered to be bound neither in contract nor in wrong. . . 3. Also he who received what is not due from one who pays it in error ... is bound as though a loan has been given ... but he who is liable on that ground cannot be considered to be liable on contract. . . 4. If a judge has made a cause his own, he does not, properly speaking, seem to be liable in wrong, but because he was not bound in contract either, yet surely is considered to have done wrong in some way, albeit through ignorance . . . he is regarded as liable as if from a wrong. 5. Also a person from whose upper floor ... something has been thrown or poured down ... is regarded as liable as if from a wrong. . . . Similar to such a person is one who keeps something placed or suspended in a place where it is general for the public to pass through, which can, if it fell down, cause harm to another. . . 6. Likewise, the man who runs a ship or an inn or a stable is regarded as being liable as if from a wrong for damage or theft which has been committed on the ship or in the inn or stable. (Trans. Watson Digest, revised.)

Later, Justinian's Institutes repeated almost verbatim, but in two separate titles (J.3.27 and J.4.5), all that the Res cottidianae had said of obligations quasi ex contractu and quasi ex delicto.

The question for us is that of the interpretation of this evolution. Why did Roman law know two classes of obligations at one point of its history, then three and then four? To put the same question from a different perspective, why was a class of obligations said to be quasi ex delicto carved out alongside the existing category of obligations ex delicto? Since a symmetrical process happened roughly at the same time on the side of lawful causative events, with obligations quasi ex contractu being added to those ex contractu, it is reasonable to assume that the two might be linked, and therefore helpful to examine them together.

The dominant interpretation has been that the process was one of extension, new categories being added to the existing ones to accommodate events which had not previously been provided for. The view argued for in this paper is that in fact the opposite process occurred: Gaius' original dichotomy was exhaustive; the quasi-categories (and indirectly the division of wrongs) did not arise from the addition of new classes but the rejection of some 
events from the original categories, following the contraction of their scope. This narrowing down of the original classes occurred on both sides of the divide between lawful and unlawful causative events, and took the form of the "essentialization" of an element of each class, which previously would have been regarded as typical but not essential. These, it is submitted, were conventio on the side of contracts and fault (culpa in the wider sense) ${ }^{8}$ on the side of delicts.

The following two sections set out the opposing views and articulate the case for the alternative proposition. On the side of delicts, the evidence is circumstantial only; but that does not in my mind stop the argument from being a cogent one.

\section{The Traditional Explanation: Addition}

\section{A. Description}

The traditional explanation of Romanists proceeds by gradual expansion. It can be summarized as follows. In G.3.88, Gaius stated that there existed two causes of obligations, contract and delict. But immediately after, in G.3.91, he realized that this was not the end of the story; there remained obligations which could not be fitted in either pigeonhole and lay beyond them. The obligation to repay a mistaken payment, which he mentions at that point, was one of them: it did not arise from a contract because there was no deal between the parties, nor obviously did it arise from a wrong: it had to arise from something else. When he came back to the question in the Res cottidianae, Gaius made allowance for the incompleteness of his original dichotomy and added a third, residuary category of causative events, the variae causarum figurae: all obligations now arose either from contract or from delict or from "various species of causes," a negatively defined residual class containing all obligations which were neither ex contractu nor ex delicto. Then, in an attempt to resolve the miscellany, Gaius linked up the variae causarum figurae, on an analogical basis, with either contract or delict. ${ }^{9}$

8 That is to say, either intentional fault (dolus malus) or unintentional fault (culpa in the narrower sense, which we might want to translate in English - albeit imperfectly — as "negligence").

9 H. Vizioz, La notion de quasi-contrat. Etude historique et critique (Bordeaux 1912), 54-55; E. Betti, "Sul significato di 'contrahere' in Gaio e sulla non-classicità della denominazione 'quasi ex contractu obligatio,", BIDR, 25 (1913), 65, 87 (stating that Gaius expressed the common wisdom of his time in G.3.88 but gives us his "real opinion" in the Res cottidianae); id., "Le fonti d'obbligazione e i problemi storici della loro classificazione," 


\section{B. Difficulties}

This theory looks appealing, not least because it is simple and follows the texts closely and in chronological order. There were two then three then four classes of obligations, and therefore the third was added to the first two and then divided up to make four. Nevertheless, it is unconvincing for several reasons.

\section{i. The Problem of the Summa Divisio}

A principal stumbling block for the above theory is the language of G.3.88, in which Gaius speaks of a "summa divisio" of obligations. Summa divisio (literally, the "highest division") was a term of art whose content was extremely strong. In Latin rhetoric, as codified by Cicero (who followed Aristotle's Rhetoric on this point), divisio entailed exhaustiveness and exclusivity: ${ }^{10}$ a divisio divides a class into subclasses, in such a way that every element of the larger set belongs to one and only one of the smaller sets.

Of course, it is possible that a writer might use the term sloppily; but the adjunction of "summa" renders this hypothesis highly implausible, especially on the part of a man for whom taxonomical considerations were at the forefront of his concerns. The image implied by the phrase summa divisio is that of a tree-like genus/species division, whose top level consists in mutually exclusive and exhaustive classes. Thus, the only reasonable interpretation of G.3.88 is that the divisio drawn was meant to be both exhaustive and exclusive: when Gaius says that the summa divisio of the causes of obligations is into contracts and delicts, he means that every possible obligation arises either from a contract or from a delict. It cannot arise from something else or from both at the same time. ${ }^{11}$

This interpretation is confirmed by the way Gaius used the phrase in the rest of the Institutes. In G.1.9: Et quidem summa

Archivio Giuridico "Filippo Serafini," 93 (1925), 267, 285; R. Monier, Cours de Pandectes (Paris n.d. [1949]), 56 (citing Albertario and ArangioRuiz); T. Mayer-Maly, "Divisio Obligationum," Irish Jurist, 2 (1967), 375, 379; P. Birks, "The Problem of Quasi-Delict," Current Legal Problems, 22 (1969), 164, 165; M. Kaser, "Divisio Obligationum," in P. G. Stein and A. D. E. Lewis, eds., Studies in Justinian's Institutes in Memory of J. A. C. Thomas (London 1983), 73, 82.

10 T. Reinhardt, ed., Cicero's Topica (Oxford 2002), 256-83, esp. 273, 280; cf. R. Zimmermann, The Law of Obligations: Roman Foundations of the Civilian Tradition (Oxford 1996), 14. The reference to Aristotle is Rhet. 2.23.9.

11 Thanks to Professor Tobias Reinhardt for his help with the argument developed in this paragraph. 
divisio de iure personarum haec est, quod omnes homines aut liberi sunt aut servi ("The summa divisio of the law of persons is this: all men are either free or slaves"), ${ }^{12}$ as well as in G.2.2: Summa itaque rerum divisio in duos articulos diducitur: nam aliae sunt divini iuris, aliae humani ("The summa divisio of things has two limbs: some things are under divine law, others under human law"), ${ }^{13}$ there is no doubt that the division was indeed meant to be complete. It would take a very powerful argument to reverse the presumption of similar exhaustiveness when it comes to G.3.88.

To this, it is sometimes retorted that the Institutes were a beginners' work, which was more interested in clarity of exposition than in comprehensiveness. There is no doubt that the first part of the statement is true; but there are two reasons which make it completely implausible to think that Gaius did not intend his summa divisio to be exhaustive. First, if that was the case, he could have very easily avoided to say anything untrue without making the argument any more complicated, for example by saying that "most obligations" arose from contract or delict, or that obligations "generally" arose from them. Such an unspecific statement would not have forced him to venture into the miscellany if he did not want to so as to keep his argument simple.

More importantly, the argument based on voluntary simplification appears to be self-defeating. Hardly had Gaius started his discussion of contracts that he drifted away to the difficult case of the solutio indebiti. His treatment of it is lengthy, complicated and so unclear that we are still wondering close to two thousand years later what exactly he meant by it. If Gaius was concerned to any significant degree with simplicity, he would logically have dispensed with a discussion of the solutio indebiti altogether. Nothing forced him to deal with it; the Institutes have no ambition to be a comprehensive exposition of the law. If he did engage in this lengthy and difficult discussion, it must be because he wanted to and felt he had to.

Here, we can without excessive presumption reconstruct Gaius' chain of thoughts. As he was writing about the mutuum, the obviously related case of the solutio came to his mind, and he saw that it seemed to challenge the validity of the statement he had just made two sentences earlier about the classification of obligations. But does it mean that he acknowledged that it was wrong? Had this been the case, we would have expected him to

12 G.1.9 (Trans. Gordon and Robinson, revised).

13 G.2.2 (Trans. Gordon and Robinson, revised). 
explain that the reason why the obligation did not arise from contract was because there was no deal; and because it did not arise from delict either, it had to arise from a third type of causative event. At this point, he would in all likelihood have gone back to his earlier statement to qualify it along the lines suggested above; or alternatively he would have carved the miscellaneous category which only appeared, several decades later, in the Res cottidianae.

But he did neither. Rather, he explained away the case of the solutio by pointing out that it did not aim at giving rise to a new obligation but at extinguishing an existing one. The suggestion which is made here is that it is not a case of a creation of obligation at all, but rather of the discharge of an obligation. It operates on a different level altogether. Naturally this is wrong, for an obligation really is contracted; but the relevant question is what Gaius was attempting to do when he wrote about the "untying" of the bond. In my mind, the only reading which makes sense of G.3.88-91 as a whole is that, far from acknowledging a flaw in his divisio, Gaius really meant to back it up by explaining that the solutio indebiti did not in fact contradict his summa divisio the way it might appear at first sight. This reading coheres with the wording of G.3.88, with the place where the solutio is examined (within contracts) and with the argument he gives for not regarding the solutio as a contractus (in effect, not that it lacks conventio but that it aims to untie a deal). It is also consistent with the fact that the divisio between contract and delict resurfaces three times in the fourth book of the Institutes, without any suggestion that it might be incomplete. ${ }^{14}$ Everything suggests that Gaius must have meant, when he wrote it, that his summa divisio was a summa divisio: all obligations arise either from contract or from delict. ${ }^{15}$

\section{ii. A Logical Difficulty}

There is, moreover, a logical problem with the traditional interpretation in terms of addition of new categories. The obligations which Gaius gave in his Res cottidianae as examples of obligations ex variis causarum figuris did not come to life between the time he wrote his Institutes (ca. 135) and the later book (in the 170s); nor could have he been unaware of their existence at the time of the former. Where then did he think that these obligations belonged

14 G. $4.2 ; 4.80 ; 4.182$.

15 Concurring with this conclusion: F. Schulz, Classical Roman Law (Oxford 1951), 467; A. Biscardi, "Some Critical Remarks on the Roman Law of Obligations," Irish Jurist, 12 (1977), 371, 375-76. 
when he wrote his Institutes? It is impossible to believe that he overlooked them altogether, be it simply because we know that he considered at least the case of the solutio indebiti. But, had he thought that they did not fit into his summa divisio, he would logically have carved the residuary class at that point or, again, toned down his statement in G.3.88. The fact that he did not is another reason to believe that, in his mind, the division was in fact exhaustive and exclusive. ${ }^{16}$

\section{An Alternative Explanation: Subtraction}

However, there is one way of solving the above difficulties, which is to abandon a postulate implicit to the analysis so far, namely, that the scope of the different categories remained static over time. There is good reason to believe that it did not.

\section{A. Description}

If we accept that Gaius meant his summa divisio to be exhaustive, the above difficulties can be solved, but we are faced in turn with a new one: how could G.3.88 and J.3.13.2 both be exhaustive summae divisiones of the law of obligations, when one comprises two categories and the other four?

Statically, this is an impossibility and at least one of them would have to be wrong. Dynamically, however, if we take into account the time span between them, two possibilities to reconcile them emerge. One is that the actions classified by Justinian as quasi-contractual or quasi-delictal came into existence between Gaius' time and his. It would then be possible for Gaius' and Justinian's classifications to be both exhaustive of obligations existing when they wrote. However, we know that this is not the case, the obligations mentioned in J.3.27 and J.4.5 already existing by the time of Gaius' Institutes.

In logic, the only other possibility is that the meaning of the categories shifted between Gaius and Justinian, and in particular that the original categories of contractus and delictum shrank, thereby effectively rendering shelterless obligations which were previously accommodated under their roof. Based on what was said earlier about the content of the categories in Justinian's

16 The suggestion that Gaius did not see obligations quasi ex delicto as obligations at all because they were praetorian bonds is unconvincing. Certainly, in the Res cottidianae, they are treated as any other obligation; and even in the Institutes, Gaius did make significant use of liabilitycreating events originating in the jurisdiction of the praetor. 
time $^{17}$ (and assuming the dividing line between lawful and unlawful events did not vary, which we have no reason to doubt), the one plausible explanation is that the factor distinguishing, in Justinian's time, contractus and delictum from their quasicontractual and quasi-delictal appendices would have been "essentialized." In other terms, conventio and culpa, which had clearly always been at least a typical characteristic of contract and delict, would have become an indispensable component of these legal categories: there could no longer exist a contractus without conventio or a delictum without culpa (in the wider sense, including dolus). The quasi-categories would then have emerged from the gathering of conventio-less lawful events and culpa-less unlawful events, which would previously have been described respectively as contractus and delicta.

\section{B. Evidence}

The above argument was purely a priori, in that it set out a hypothesis which logic dictates ought to be true if we accept that G.3.88, like J.3.13.2, means what it says and accurately reflects the law of its time: subject to the above specifications, if all obligations were either ex contractu or ex delicto at stage 1 (G.3.88) and either ex contractu or quasi ex contractu or ex delicto or quasi ex delicto at stage 2 (J.3.13.2), then the category "ex delicto" of stage 1 must by construction square with those "ex delicto" and "quasi ex delicto" at stage 2 - and likewise on the contractual side. In turn, this can only be explained by the fact that the scope of the categories ex contractu and ex delicto are narrower at stage 2 than stage 1.

Do we, however, have any factual evidence in the sources in support of this hypothesis? The answer is that we do find ample corroborative evidence on the lawful side of causative events (contracts and "quasi-contracts"), but not on the unlawful side (delicts and "quasi-delicts"). When it comes to the latter, the evidence is only circumstantial: it lies in the fact that the theory fits the available data, and makes sense of the otherwise incomprehensible difficulties put forth above. As will be seen, ${ }^{18}$ it is also supported by a similar contraction in the scope of liability under the lex Aquilia. Along with the previous apodictic argument and the analogical argument from the narrowing down of contractus, this provides what is in my mind a strong case for the "shrinkage theory."

17 Figure 1, above at 4.

18 Below at 17. 


\section{i. The Narrowing Down of the Concept of Contract}

The theory that the scope of the concept of contractus narrowed down during the classical age of Roman law was first articulated by Henry Vizioz in 1912 and can be summed up as follows. ${ }^{19}$ "Contractus" was originally the Latin translation of Greek

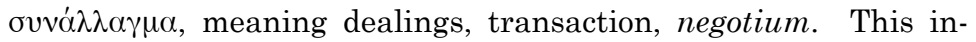
cluded all lawful, bilateral juridical (i.e. obligation-creating) acts, whether founded on the agreement of the parties or not. However, at some stage in the development of Roman law, the meaning of the category came to shrink, from $\sigma v v \alpha \dot{\lambda} \lambda \alpha \gamma \mu \alpha$ to what is expressed by the Latin word pactum in its wider sense, that is, a ovvó $\lambda \lambda \alpha \gamma \mu \alpha$ founded on an agreement of the minds of the parties (conventio) - a meaning that, essentially, the word "contract" has kept till the present day. ${ }^{20}$

When and why this happened is not unequivocally clear. As to timing, Vizioz suggested soon before the time of Gaius' Institutes, because these still show traces of a struggle between the old and the new conception of contractus. But more likely, no precise time can be pinpointed. No one engineers the shifts in meaning that words occasionally experience; they just happen, and they happen gradually, some being quicker to embrace the new conception than others. This must have been the case for contractus as well.

The evidence available (assuming no interpolation of the texts) fits this theory well. As early as Pedius, a lawyer who lived under the reign of Hadrian (AD 117-138), we find the new mean-

19 Vizioz (note 9), chapter 4, esp. 43-54. Subsequently agreed with Vizioz: S. Perozzi, Istituzioni di diritto romano, 2, 2nd ed. (Rome 1928), § 124; E. Albertario, Studi di diritto romano, 3 (Milan 1936), 77-81, 103; E. Betti, Istituzioni di diritto romano, 2, 2nd ed. (Padua 1947), 68 (describing the addition of the element of consensus in the notion of contractus as a "late evolution"); G. Grosso, Il sistema Romano dei contratti, 3rd ed. (Turin n.d. [1963]), 11; Biscardi (note 15), 373-75, 377-78. Contra: S. Riccobono, Dal diritto Romano classico al diritto moderno (Palermo 1915), 290; W. W. Buckland, The Main Institutions of Roman Private Law (Cambridge 1931), 240 (although he does recognize that certain texts use "contractus" in a wider sense).

20 One difficulty with the thesis is that it does not generally distinguish between the verb, contrahere, and the noun, contractus, whereas it is plain that the former is wider in scope than the latter: still today, in English, I can "contract" a disease without having signed a contract to that effect. But the thesis still stands even if one sets aside the texts where only "contrahere," to the exclusion of "contractus," appears. 
ing of contractus as pactum reported by Ulpian; ${ }^{21}$ on the other hand, Paul and Ulpian himself, in the early third century, still referred to the negotiorum gestio or the tutela, both to be later classified as "quasi-contracts" in Justinian's Institutes, as contractus. ${ }^{22}$ This is evidence of the fact that a wider meaning of contractus, which did not entail conventio, existed at a time and then gradually disappeared from the legal landscape, albeit not in a uniform fashion.

Gaius falling in between the two, we can assume that his time was one of tension between contractus as ovvó $\lambda \lambda \alpha \gamma \mu \alpha$ and contractus as pactum. (This would indeed make perfect sense of

21 D.2.14.1.3 (Ulpian 4 ed.): Adeo autem conventionis nomen generale est, ut eleganter dicat Pedius nullum esse contractum, nullam obligationem, quae non habeat in se conventionem . . . . ("Moreover, so true is it that the word 'agreement' has a general significance that Pedius neatly says that there is no contract, no obligation which does not consist of agreement ....” Trans. Watson Digest.)

22 For negotiorum gestio, see D.3.5.15(16) (Paul 7 Plaut.): Sed et cum aliquis negotia mea gerat, non multa negotia sunt, sed unus contractus, nisi si ab initio ad unum negotium accessit, ut finito eo discederet: hoc enim casu si nova voluntate aliud quoque adgredi coeperit, alius contractus est. ("Again, when someone transacts business of mine, it is not a number of transactions but a single contract, unless initially he took on only one transaction with the intention of getting out on its completion. For in this case, if he makes a fresh decision to tackle another as well, it is a different contract." Trans. Watson Digest, revised.) For tutela, see D.13.5.1.6 (Ulpian 27 ed.): Debitum autem ex quacumque causa potest constitui, id est ex quocumque contractu sive certi sive incerti, et si ex causa emptionis quis pretium debeat vel ex causa dotis vel ex causa tutelae vel ex quocumque alio contractu. ("A constitutum can be made in respect of a debt arising from any cause, that is, from any contract of fixed or unfixed content, or a debt in respect of a price under a sale, or else on the basis of dowry or of a tutelage or any other contract whatever." Trans. Watson Digest) and D.44.7.49 (Paul 18 Plaut.): Ex contractibus venientes actiones in heredes dantur, licet delictum quoque versetur, veluti cum tutor in tutela gerenda dolo fecerit aut is apud quem depositum est: quo casu etiam cum filius familias aut servus quid tale commisit, de peculio actio datur, non noxalis. ("Actions arising from contracts are available against the heirs, even if a wrong is also involved, for example, if a tutor in the administration of his tutelage, or a person with whom property has been deposited, acted fraudulently; in such a case even when a son-in-power or a slave has committed a wrong of this kind, an action on the peculium, and not a noxal action, is allowed." Trans. Watson Digest.) For both negotiorum gestio and tutela, see D.50.17.23 (Ulpian 29 Sab.): Contractus quidam dolum malum dumtaxat recipiunt, quidam et dolum et culpam. . . Dolum et culpam mandatum, commodatum, venditum, pignori acceptum, locatum, item dotis datio, tutelae, negotia gesta. ("Some contracts involve bad faith, some also culpability. ... Mandate, loan for use, sale, acceptance in pledge, hire, likewise grant of a dowry, grant of tutelage, unauthorized administration involve bad faith and culpability." Trans. Watson Digest.) 
the evolution in his works, the Institutes reflecting the older approach and the Res cottidianae the newer). Vizioz pointed out that the Institutes show this tension between the wider and narrower senses of the term. There, Gaius was tempted to deal with solutio indebiti as a contract, as evidenced by the place where he deals with it. As was seen, he renounced - not because of the absence of consent but because, he said, the operation aimed at distrahere and not at contrahere; however, the place where it is discussed is highly significant: it is G.3.91, just after mutuum, i.e. within contracts. His starting point must have been that the solutio indebiti was a contract, which presumably was still the dominant opinion of his time. Gaius' unease regarding non-consensual contracts is plainly visible in this passage: on the one hand, he could not bring himself to classify the solutio as a contractus; on the other, he would not write, like his contemporary Pedius, that contractus entails conventio, which was lacking in the case of the solutio. As a result, he was forced to explain away the case of the mistaken payment through a different (and unconvincing) means. ${ }^{23}$

This unease might also explain why Gaius makes no mention at all in his Institutes of the other obligations which he would later classify as quasi ex contractu or quasi ex delicto. Most likely, he simply did not know what to make of them, sensing that he could not properly include them under the headings of "contracts" or "delicts," yet not having taken the decisive step of creating another category to accommodate them. In contrast, by the time of the Res cottidianae, he had bridged the gap to the newer (and narrower) meaning of contractus as pactum, which was reflected in his categorization of solutio indebiti, negotiorum gestio, and others as quasi ex contractu. ${ }^{24}$

It is not my concern here to venture possible explanations for this shrinkage. Its historicity is well grounded in the texts, and what matters for the present purpose is only its consequences on the classification of obligations. The principal consequence is that, while those actions formerly described as ex contractu but where no agreement could be found did not disappear from the legal landscape, they could no longer be called contractual. They were, in effect, quasi-contractual: they produced the very same

23 Above at 11.

24 It is also interesting to compare G.4.182, where there does not seem to be a way around the conclusion that Gaius is implicitly calling tutelage a contractus, with D.44.7.5.1 (from the third book of Gaius' Res cottidianae), where it is explicitly referred to as a cause of obligation quasi ex contractu. 
effects as contractual obligations (a feature of which this interpretation makes complete sense, since this is what they would originally have been); but they did not arise from contract in the narrower sense. They arose as if there had been a contractpactum, quasi ex contractu - hence both the category and its name.

\section{ii. The Narrowing Down of the Concept of Delict}

As was mentioned, there is no similar textual evidence of shrinkage on the side of unlawful causative events: we do not possess earlier texts where an obligation was described as ex delicto and later texts where it is categorized as quasi ex delicto. The evidence is circumstantial only. What can be done in this section, however, is provide an illustration of a similar phenomenon of contraction, and a tentative explanation of why such a shrinkage would have occurred.

\section{The parallel with the lex Aquilia}

While there is no direct evidence of the shrinkage of the concept of delictum in Roman law, there is such evidence of the narrowing down of the grounds of liability within the delictal class in respect of the wrong of damnum iniuria datum (loss wrongfully caused under the provisions of the lex Aquilia and the related actiones utiles). This is significant because it constitutes an illustration of the rise of culpa as a condition of liability in delict, which entails in logic the creation of the quasi-delictal appendix. ${ }^{25}$ For this reason, it constitutes strong indirect evidence for the present hypothesis.

Even if our knowledge of the words of the action is imperfect, it is not doubted that the wording of the lex Aquilia made no reference to fault. Liability attached, at least on the face of it, to the occurrence of certain events: it was situational. However, these events were not defined randomly; by their very nature they normally resulted from intentional misconduct. It is equally certain that by the time of Gaius, at the latest, liability under the lex Aquilia had been restricted to culpable conduct in the wider sense: as he writes in his Institutes, "a person kills wrongfully when the death happens by his malicious intent or by his fault ... and so no liability is imposed on someone who inflicts loss without

25 Or else the re-categorization of cases of strict liability as being based on lawful events. This avenue was not followed by the Romans, but would be by some lawyers of the ius commune, in particular Molina (see note 40 below and accompanying text). 
either fault or malicious intent, but by some accident." 26 This is a perfect illustration of what is suggested in this article was a general transformation of delictal liability, from situational to culpa-based.

Again, in the face of the lack of evidence, how this transformation occurred is bound to be largely a matter of speculation. Professor Ibbetson has suggested that it was brought about by the need to decide to whom responsibility should be affixed in the case of a plurality of causal agents: it would be to him who was to be blamed, who had acted culpa. ${ }^{27}$ However, this does not explain why it became a general principle of liability under the lex Aquilia, even in the case of a single potential defendant. As is apparent from Gaius' statement, couched in the most general terms, the requirement of culpa came to be regarded as an integral part of Aquilian liability. Because this was not included in the original words, the most obvious explanation is to surmise that the odd innocent defendant, feeling naturally (as we would) that an injustice was being done to him, pleaded casus, the accidental occurrence of the loss, as a defence. ${ }^{28}$ Gaius' text evidences that such defendants were consistently successful, to the point where it was accepted by all that no liability under the lex would attach to accidental wrongdoing. By subtracting casus, lawyers had effectively (if indirectly) reduced Aquilian liability to liability for fault-culpa.

\section{Poena and culpa}

If we accept that the concept of a delict shrank, in classical Roman law, from an unlawful civil act to a blameworthy such act (containing either dolus or culpa on the defendant's part), the next question becomes why such a shift would have occurred.

It is always dangerous to speculate as to the causes of events historically so remote, especially when few hard facts are available. However, in the present case, common sense does suggest an easy explanation, which can be offered tentatively. The argument has to do with the characteristics of early systems of civil

26 G.3.211 (Trans. Gordon and Robinson).

27 D. Ibbetson, "How the Romans did for Us: Ancient Roots of the Tort of Negligence," U. New S. Wales L.J., 26 (2003), 475, 495-97.

28 As long as liability under the lex Aquilia was limited to the direct causation of harm, the problem would have remained unimportant in practice. A directly inflicted injury is typically intentional. It is when the praetor started to extend liability on an analogical basis to indirectly caused loss that issues of blameworthiness (intertwined with questions of causation) would have come to the fore. 
liability as result-oriented, and with the penal character of the Roman law of civil wrongs. Kaser has convincingly shown that earlier liability was what he called "typified liability for fault" (in fact, for intentional fault):

In the earliest period, all peoples took into account the externally visible event, the act, and imputed the act to any wrongdoer who had caused the result. However, probably everywhere and from early times, this was based on the experience that somebody who committed typical acts resulting in a loss, mostly intended also to inflict loss; the ancient strict liability, therefore, in reality was a typified liability for fault. ${ }^{29}$

What was penalized was the loss caused, but the redressable loss was defined in such a way as to normally entail intention to harm. This is intuitive.

But equally intuitive is the fact that the issue of intent was bound to come up at a later stage. A slave has his throat cut: this is paradigmatically the result of a wicked, intentional assault. It is plainly wrong, and will be penalized by the law. Liability, at least on the face of it, will be for slaying the slave. It will attach to the occurrence of a particular event. But sometimes the situation will not be so simple. The slave might have attacked the killer. That the defendant would escape liability if he had acted in self-defence is, again, quite plain in regard of common morality. Rationalized by lawyers, this will lead to the specification that the killing must have been done without justification, iniuria; and self-defence provides (under circumstances to be refined by the law) such a right to kill. The slave was killed deliberately, but justifiably rather than wickedly. Then again, he might not have been killed intentionally. He might, in some cases which common sense suggests must be rare, have been killed accidentally and in others, which in a quasi-autarkical society must have been incomparably less frequent than today, negligently so. Should the doer of the act escape liability in these cases?

An untutored perception suggests that the answer depends on what goal or goals are ascribed to the imposition of liability. If the goal is to punish, the answer seems to be yes, "it being useless to apply a sanction where the will is passive," as John Austin phrased it in the nineteenth century. ${ }^{30}$ As a matter of fact, Pro-

29 M. Kaser, Roman Private Law, trans. R. Dannenbring, 3rd ed. (Pretoria 1980), 186.

30 J. Austin, The Province of Jurisprudence Determined, followed by 
fessor Ibbetson has documented how criminal responsibility crystallized historically out of legal provisions dependent on the voluntariness of the act (as distinct from civil liability, concerned with the comparison with an external standard of conduct). ${ }^{31}$ This makes complete sense. Indeed, even though the more recent history of criminal law has made some inroads into this principle, it is plain that intentional conduct is still of the essence of crime. If, on the other hand, the objective is to compensate the victim for the harm suffered, the answer becomes much less clear. There is on the one hand someone who caused harm without meaning to and on the other hand a (normally innocent) victim who suffered damage. Where should the loss lie? It is at least a possibility to hold that the causal agent has to bear it. (This is of course all the easier to hold if he is to blame in a milder sense, not that he meant to cause the loss but that he could have avoided the result had he been diligent.)

Legal systems do not normally make explicit what the goals of their liability in wrongs are; but this can largely be reconstructed from the rules they apply, be it the definition of wrongful events or the legal consequences attached to them. In systems which do not distinguish between criminal and civil wrongs, the one class of wrongs is bound to be the vehicle for punishment, compensation, and other possible aims, all at one time. In systems which do distinguish between them (as later Roman law did), history shows that less emphasis will be put in the case of civil wrongs on punishment and more on compensation. Again, this is commonsensical.

In modern legal systems, it has been a temptation to claim that civil wrongs were exclusively about compensation, punishment being the realm of criminal law. In the Roman law of delicts, on the other hand, the punitive component is not only plainly visible, but prominent: even though considerations of compensation are also present, it is transparent that the main emphasis is on the punishment of the wrongdoer through the infliction of the poena (penalty). The Roman law of wrongs can therefore be adequately described as a penal law. ${ }^{32}$ Actions, both delictal and quasi-delictal, ${ }^{33}$ were penal (either exclusively or in

Lectures on Jurisprudence, 3, 2nd ed. (London 1863), 134.

31 D. Ibbetson, "Wrongs and Responsibility in Pre-Roman Law," J. Legal Hist., 25 (2004), 99.

32 Schulz (note 15), 573; M. Kaser, Das römische Privatrecht, 1, 2nd ed. (Munich 1971), 610.

33 Y. Chastaignet, Contribution à l'étude historique et critique de la 
part). They had, in Kaser's word, the purpose to make the wrongdoer "expiate" his act. ${ }^{34}$

This, in itself, does not entail that liability in wrongs will be dependent on culpa in the wider sense. But it makes it logical: in reason, there can be liability without fault, but there cannot be poena without culpa; if that happens to be the case because of the way the system developed historically, it must be regarded as anomalous and kept to its fringes, for instance in a "quasiwrongful" class. Punishment naturally brings about the requirement of fault. Imperfect as the equivalence might be at any given time, there is an evident connection between poena and culpa: the farther one goes in the direction of punishment, the more emphasis will be put on wicked intent; conversely, the more emphasis is put on compensation, the less important it will naturally become. This does not mean that the Roman law of civil wrongs was bound to settle on culpa as its minimal requirement for liability in delict. It could have been otherwise (for example, liability could have been made dependent on dolus malus, as indeed it was in three of the four institutional wrongs). ${ }^{35}$ But it does make it completely intelligible that this is what it did, and especially that it excluded accidents from the scope of liability in wrongs "proper." Instances of strict liability cannot be reconciled in a principled manner with the infliction of a penalty upon the wrongdoer. Thus, apart from the circumstantial historical evidence, the thesis defended in this paper appears to be intrinsically plausible.

\section{Conclusion}

This article, building on the assumption that quasi-delictal liability corresponded in Roman law to situational liability, has attempted to provide a rationale for the distinction between two classes of wrongs, delicts and "quasi-delicts." Starting from the observation that the division did not always exist in the institutional taxonomy of the law, Gaius having really meant his summa divisio in G.3.88 to be a summa divisio, it hypothesized that the emergence of the quasi-delictal appendix was brought about by a

notion de quasi-délit (Bordeaux 1927), 31.

34 M. Kaser (note 29), 249.

35 It is probably no coincidence that the one delict where culpa was sufficient to trigger liability, damnum iniuria datum, was also the one where the punitive dimension of the law's response to the commission of the wrong was least prominent. 
contraction of the meaning of delictum, from an unlawful civil act to a culpable (i.e. blameworthy) such act. This contraction was mirrored on the lawful side of causative events by that of contractus, from ovvó $\lambda \lambda \alpha \gamma \mu \alpha$ to pactum. While the latter shift is documented in the sources, the former is not. The argument is $a$ priori; but it is supported by significant circumstantial evidence, starting with the fact that it makes sense of the twin classifications of obligations in G.3.88 and J.3.13.2 in a way other theories do not.

If the "shrinkage hypothesis" is true, it has interesting repercussions for the modern law, and in particular for the jurisprudential analysis of the concept of a civil wrong. By and large, modern law accepts that the law of wrongs is made of two strands, fault-based liability and liability irrespective of fault. ${ }^{36}$ Certainly, the common law has never had any difficulty with the proposition that the duty of which a wrong is the breach can be a strict duty just as much as a duty of care. ${ }^{37}$ The civilian tradition, on the other hand, has exhibited greater hesitation. While a system like French law would accept nowadays the existence of strict as well as fault-based liability within its law of civil wrongs, historically it has attempted more than once to reduce both tracks to one, either by denying the factual existence of wrongs not based on culpa or, more recently, by widening the concept of fault from historical culpa to something akin to a breach of duty, regardless of the content of the duty. ${ }^{38}$ Still today, some civilian voices can be heard suggesting that a wrong is necessarily, or at least appropriately, the breach of a duty of careful behavior. ${ }^{39}$ Instances of what we would otherwise call strict liability (typically based on the taking of a special risk) would then find themselves rejected outside the law of wrongs altogether, and transferred to the lawful side of causative events. On this view, "strict liability" is based on the implicit promise to pay compensation if the dangerous action happens to injure others: taking a risk is lawful, but

36 E.g. Zimmermann (note 10), 22; J. Esser, "Die Zweispurigkeit unseres Haftpflichtrechts," Juristenzeitung, 8 (1953), 129.

37 A. Burrows, ed., English Private Law, 2nd ed. (Oxford 2007), $\S 17.18 \mathrm{n}$. For an analysis of wrong as a breach of duty, see generally P. Birks, "The Concept of a Civil Wrong," in D. G. Owen, ed., Philosophical Foundations of Tort Law (Oxford 1995), 31, 33, 37.

38 Descheemaeker (note 2), chapters 5-6.

39 E.g. N. Jansen, "Duties and Rights in Negligence: A Comparative and Historical Perspective on the European Law of Extracontractual Liability," Oxford J. Legal Stud., 24 (2004), 443, 446. 
taking it without accepting responsibility for the consequences is not.

Is a wrong the breach of a duty simpliciter or the breach of a duty of careful behavior? In this debate, Gaius appears to have steered a unique middle course which, in my mind, can be regarded as the root of modern hesitancies about the concept of a civil wrong. If the hypothesis developed in this paper is correct, between the time of the Institutes and that of the Res cottidianae, Gaius accepted that a wrong could only properly be called a wrong if it contained an element of blameworthiness (culpa or dolus). However, he did not eliminate instances of unculpable liabilitycreating events from the legal landscape, nor did he re-categorize them, as Molina later would, ${ }^{40}$ as lawful events. Rather, he consigned them to an unlawful but non-wrongful limbo, thereby driving a wedge between the two notions. In Gaius' sense, wrongfulness is narrower than unlawfulness: an event can be prohibited by the legal system and attract civil liability, even though it is not blameworthy and cannot therefore be called a delict.

It is not clear how this proposition can be defended on its merits; arguably, strict liability should either be recognized as part and parcel of the law of wrongs (if possibly a special subpart of it, which is a separate issue), or eliminated altogether. Be that as it may, we can recognize Gaius' taxonomical choice as the origin of the modern tension between the two notions. The uneasy area of unlawfulness without wrongfulness, which was labelled "quasi-wrongful" by Gaius, continues to be a cause of trouble for us today; and modern lawyers are still not in agreement as to how we should understand it. This is another example of the way in which our thinking about the law is constrained by the choices that others made for us long before our legal systems even existed.

40 Luis de Molina, De justitia et jure, 3 (Mainz 1659), 154 (= Tract. II, Disp. 698, n. 3): the obligation to pay compensation arises "non quidem ratione culpae theologicae, sed ratione pacti, seu quasi pacti." 